\title{
Phytoplankton assemblage patterns in the southern Mid-Atlantic Bight
}

\author{
Carla P. Makinen ${ }^{1}$ and Tiffany A.H. Moisan ${ }^{2, *}$ \\ ${ }^{1}$ URS Corporation, NASA/GSFC Wallops Flight Facility, \\ Wallops Island, VA 23337, USA \\ ${ }^{2}$ Wallops Field Support Office, Code 610.W, \\ Atomspheric Sciences Room E-217, Bldg. N-159, \\ NASA/GSFC Wallops Flight Facility, Wallops Island, \\ VA 23337, USA, e-mail: tiffany.a.moisan@nasa.gov \\ *Corresponding author
}

\begin{abstract}
As part of the Wallops Coastal Oceans Observing Laboratory (Wa-COOL) Project, we sampled a time-series transect in the southern Mid-Atlantic Bight (MAB) biweekly. Our 2-year time-series data included physical parameters, nutrient concentrations, and chlorophyll $a$ concentrations. A detailed phytoplankton assemblage structure was examined in the second year. During the 2-year study, chlorophyll $a$ concentration (and ocean color satellite imagery) indicated that phytoplankton blooms occurred in January/February during mixing conditions and in early autumn under stratified conditions. The chlorophyll $a$ concentrations ranged from $0.25 \mu \mathrm{g} \mathrm{l}^{-1}$ to $15.49 \mu \mathrm{g} \mathrm{l}^{-1}$ during the 2-year period. We were able to discriminate approximately 116 different species under phase contrast microscopy. Dominant phytoplankton included Skeletonema costatum, Rhizosolenia spp., and Pseudo-nitzschia pungens. In an attempt to determine phytoplankton species competition/succession within the assemblage, we calculated a Shannon Weaver diversity index for our diatom microscopy data. Diatom diversity was greatest during the winter and minimal during the spring. Diatom diversity was also greater at nearshore stations than at offshore stations. Individual genera appeared patchy, with surface and subsurface patches appearing abruptly and persisting for only 1-2 months at a time. The distribution of individual species differed significantly from bulk variables of the assemblage (chlorophyll $a$ ) and total phytoplankton assemblage (cells), which indicates that phytoplankton species may be limited in growth in ways that differ from those of the total assemblage. Our study demonstrated a highly diverse phytoplankton assemblage throughout the year, with opportunistic species dominating during spring and fall in response to seasonal changes in temperature and nutrients in the southern MAB.
\end{abstract}

Keywords: coastal; diversity; Mid-Atlantic Bight; phytoplankton; time series.

\section{Introduction}

An increasing amount of research has focused on the response of marine ecosystems to alterations in phytoplankton diversity resulting from global climate change (Moisan et al. 2011, 2012). Little is known about how the phytoplankton assemblage, at the species level, responds to human-induced perturbations. There is a need for long-term time-series data from coastal areas where there is significant human impact to understand how climate affects marine ecosystems. Many large-scale programs, including the Joint Global Ocean Flux Study (JGOFS), Bermuda Atlantic Time-Series Study (BATS), and Hawaiian Ocean Time Series [HOTS; (Chavez et al. 1990, Malone et al. 1993, Karl et al. 2001)], have addressed spatial and temporal variability over long time periods and have emphasized that carbon flow is mediated by phytoplankton species composition and productivity. The National Oceanic and Atmospheric Administration's Integrated Ocean Observing System (NOAA’s IOOS) program vision was to create "a fully integrated ocean observing system” in the coastal regions to understand the relationship between climate and ecosystems for "sustained living marine resources" (NOAA 2007). One of our goals was to determine the underlying parameters that drive changes in phytoplankton assemblage composition and, therefore, carbon flow to better predict the effects of climate change. Temperature, a critical variable that determines phytoplankton succession as well as light and nutrients, affects phytoplankton diversity and perturbations in assemblage structure (Moisan et al. 2002, Smayda et al. 2004).

Our study focuses on phytoplankton dynamics near the Delmarva Peninsula, which is located in an area under the influence of Chesapeake and Delaware Bays on the east coast of the USA. Previous studies and satellite imagery do not suggest that our study area is significantly impacted by either of these bays. There have been excellent descriptive studies of phytoplankton assemblage composition in the coastal region of the Delmarva Peninsula (Marshall 1976, 1984, Marshall and Cohn 1987). Studies in Chesapeake and Delaware Bays have extensively assessed nutrient dynamics and primary productivity in relation to hydrographic conditions, and spatial and temporal variability in phytoplankton assemblage structure (see Watling et al. 1979, Harding et al. 1986, Marshall and Lacouture 1986, Fisher et al. 1992, Roman et al. 2005). The dynamics of the coastal phytoplankton assemblage are less known in relation to nutrient availability, vertical structure, and physical influences. However, assessment of the Delmarva coastal region is important to: 1 ) develop a baseline understanding of the assemblage for long-term climaterelated assessments, 2) improve productivity estimates, and 3) improve our understanding of the influence of phytoplankton diversity on biomass and primary productivity. 
The study area was in the southern Mid-Atlantic Bight (MAB), off the coast of Assateague Island (Virginia); it is located near the NASA Goddard Space Flight Center Wallops Flight Facility. The Gulf Stream flows northward further offshore. Temperate species are dominant in the region, with subtropical species sometimes appearing in warm core rings originating from the Gulf Stream (Cox and Wiebe 1979). Waters in the region are typically well-mixed in the winter months, with strong stratification in the summer.

We investigated physical, chemical, and biological parameters at five stations along a transect extending from approximately $9.6 \mathrm{~km}$ to $40.7 \mathrm{~km}$ offshore (Figure 1, Table 1 ). The stations ranged in depth from approximately $9 \mathrm{~m}$ to $32 \mathrm{~m}$ (Table 1). Phytoplankton species were examined at Stations 1 and 5 to analyze community structure and to gain a better understanding of the forces affecting the phytoplankton assemblage. We also examined the vertical structure of the assemblage to assess the intrusion of high-nutrient waters, the influence of irradiance, and the occurrence of a bottom chlorophyll $a$ maximum. Biological, physical, and nutrient data were obtained from a series of cross-shelf transect cruises from June 2005 to December 2007 as a part of the Wallops Coastal Ocean Observation Laboratory (Wa-COOL) Project. Cruises were conducted bi-weekly to monthly, weather permitting, aboard the Marine Science Consortium's RV Phillip N. Parker. Stations ranged from approximately $9.6 \mathrm{~km}$ (Station 1) to $40.7 \mathrm{~km}$ (Station 5) offshore from Assateague Island (Virginia) in the southern MAB (see Figure 1 and Table 1).

Although we examined the physical parameters, nutrient patterns, and biological characteristics at all five stations, the phytoplankton assemblage structure data were acquired at only Stations 1 and 5. These stations were chosen because of the distance from each other and include coastal and oceanic phytoplankton communities. At each station, the same discrete depths were sampled on each cruise (Table 1). In addition to comparing assemblages immediately offshore vs. those further offshore, sampling various depths allowed

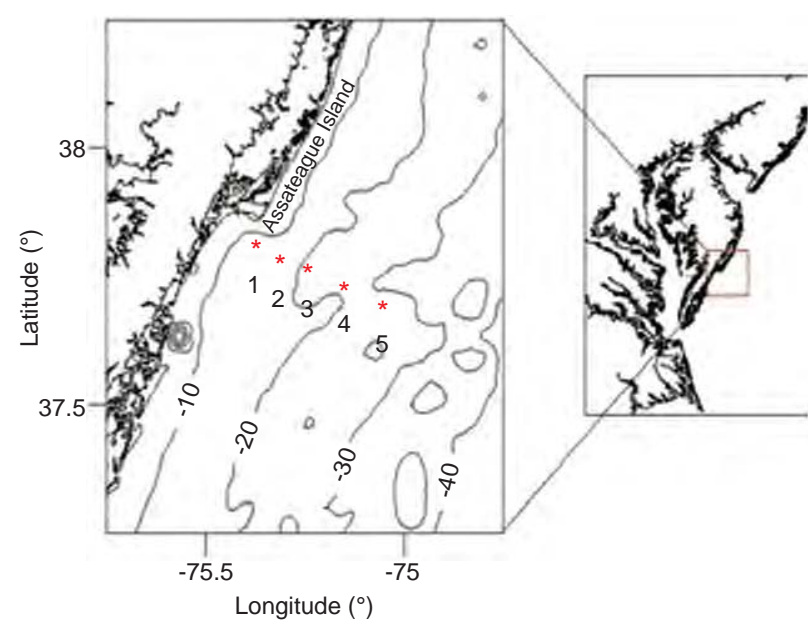

Figure 1 Cruise transect stations (red) offshore from Assateague Island. Stations are numbered, with Station 1 closest to coastline, and proceed to Station 5 furthest offshore.
Table 1 Station information.

\begin{tabular}{llllrl}
\hline $\begin{array}{l}\text { Station } \\
\text { Latitude } \\
\text { (N) }\end{array}$ & $\begin{array}{l}\text { Longitude } \\
(\mathrm{W})\end{array}$ & $\begin{array}{l}\text { Distance } \\
\text { from } \\
\text { shore }(\mathrm{km})\end{array}$ & $\begin{array}{l}\text { Total } \\
\text { depth } \\
(\mathrm{m})\end{array}$ & $\begin{array}{l}\text { Depths } \\
\text { sampled (m) }\end{array}$ \\
\hline 1 & 37.8164 & 75.3753 & 9.6 & 9.0 & $0,4,7$ \\
2 & 37.7913 & 75.3144 & 15.7 & 12.0 & $0,6,9$ \\
3 & 37.7697 & 75.2449 & 22.2 & 21.0 & $0,5,10,15$ \\
4 & 37.7386 & 75.1507 & 31.3 & 23.0 & $0,5,10,20$ \\
5 & 37.6991 & 75.0543 & 40.7 & 32.0 & $0,5,10,20,29$ \\
\hline
\end{tabular}

assessment of the vertical components of phytoplankton assemblage structure.

The phytoplankton assemblage was dominated by diatoms during the spring and fall blooms, with high diversity during the summer. Nutrients never became limiting in the area, but there were other competing sources of carbon during summer, as demonstrated by high Redfield ratios. Grazing appeared to control the taxonomic composition of the assemblage, especially with respect to Cyanobacteria (Moisan et al. 2010, J. Ambler et al. unpublished observations). Despite strong stratification, we often observed a well-developed chlorophyll maximum above the sandy bottom where nutrients were low.

\section{Materials and methods}

Depth-specific water samples were collected either by bucket (surface samples) or Niskin bottle, and held at in situ temperatures until processing (Table 2). Upon return to the laboratory, $20 \mathrm{ml}$ samples were filtered under negative pressure $<5$ mm Hg, preserved with $2 \%$ glutaraldehyde (final concentration), stained with proflavine (final concentration $5 \mu \mathrm{g} \mathrm{ml}^{-1}$ ), and immediately filtered onto $2.0 \mu \mathrm{m}$ black polycarbonate filters (GE Osmonics, Swedesboro, NJ, USA), using $8.0 \mu \mathrm{m}$ nitrocellulose backing filters to ensure an even distribution of cells during filtration (modified from Sherr et al. 1993, Kemp et al. 1993). Polycarbonate filters were placed on moistened microscope slides, a drop of immersion oil was added, and a coverslip was added. Prepared slides were stored in a freezer until analysis.

\section{Phytoplankton assemblage composition by epifluorescence microscopy}

Phytoplankton taxa from net tows (mesh size $20 \mu \mathrm{m}$ ) were preserved and used to identify taxa $>20 \mu \mathrm{m}$, resolved to

Table 2 Seasonal mean fluorometric chlorophyll concentrations $( \pm \mathrm{SD})$.

\begin{tabular}{lllll}
\hline & Winter & Spring & Summer & Autumn \\
\hline Station 1 & $6.40( \pm 1.44)$ & $4.23( \pm 2.68)$ & $5.51( \pm 3.86)$ & $5.81( \pm 1.71)$ \\
Station 2 & $4.88( \pm 1.61)$ & $3.16( \pm 2.39)$ & $3.21( \pm 3.33)$ & $4.22( \pm 1.22)$ \\
Station 3 & $4.61( \pm 2.88)$ & $2.21( \pm 1.24)$ & $2.07( \pm 1.53)$ & $3.72( \pm 2.65)$ \\
Station 4 & $3.89( \pm 1.86)$ & $1.98( \pm 1.11)$ & $1.49( \pm 1.30)$ & $1.80( \pm 1.08)$ \\
Station 5 & $3.26( \pm 1.93)$ & $1.93( \pm 1.30)$ & $1.43( \pm 1.65)$ & $1.95( \pm 1.57)$ \\
\hline
\end{tabular}

Dimensions are $\mu \mathrm{g} \mathrm{l}^{-1}(\mathrm{n}=3)$. 
genus or species level. Microscopic analysis was performed under an Olympus (Tokyo, Japan) BX-51 compound microscope with a mercury light source and a fluorescence filter cube (Olympus 41015) for proflavine fluorescence. An ocular grid was used to count ten fields on each slide, and fields were systematically chosen to cover all areas of the filter to take into account potentially uneven distributions of cells. Fields were identified, and initial counts and identifications were performed under $400 \times$ magnification. For small cells within the field, an oil immersion 100× objective lens was used as well. When very few cells were included in ten fields, additional fields were counted. All quantitative counts were made with whole water samples and were counted on filters using epifluorescence microscopy. Net tows were used only as a qualitative measure. We utilized different methods to reduce our error due to uneven distribution of cells and found that our \% error results were within a coefficient of variation of 20\% (Moisan et al. 2010).

Individuals that could not be identified down to the genus level were assigned unique four-digit identification numbers for classification purposes following Fryxell and Hasle's conventions (Tomas 1997). Unknown diatoms were also classified as either centric or pennate. Known and unknown dinoflagellates were assigned to distinct size categories $(<20 \mu \mathrm{m}, 20-40$ $\mu \mathrm{m}$, and $>40 \mu \mathrm{m}$ ). With the exception of a few obvious species, flagellates were pooled together in a "flagellates" category because we did not have access to electron microscopy, which is needed for identifying these very small organisms. In general, we found high diversity, with approximately 116 species that we were able to resolve with our methodology (Table 3).

\section{Conductivity, temperature, depth (CTD)}

A Sea-Bird 49 CTD (Bellevue, WA, USA) integrated into an optical profiling package was deployed at all stations on transect cruises to measure conductivity and temperature through all depths of the water column. For data collection, the profiler was lowered to the water surface for at least 2 min to allow ample time for equilibration. The profiler was then lowered to $2 \mathrm{~m}$ above the seafloor and raised at a speed of approximately $0.5 \mathrm{~m} \mathrm{~s}^{-1}$ while logging data at a rate of 1 Hz. Once back in the laboratory, CTD data were extracted from the profiler's WetLabs (Philomath, OR, USA) DH-4 data handler and processed. We converted from pressure (decibar) to depth (meters) following Sea-Bird's Application Note 69 (from UNESCO 1983). Density was calculated using the UNESCO 1983 (EOS 80) polynomial. Finally, all data were binned at 1-m intervals and used to create water column profiles.

\section{Fluorometric chlorophyll a}

Phytoplankton counts were also compared with chlorophyll $a$ data collected on each transect cruise. Water samples for fluorometric chlorophyll $a$ and microscopic measurements were taken from the same Niskin bottles to ensure that we were sampling a consistent phytoplankton assemblage. Samples were collected on $0.7 \mu \mathrm{m}$ Whatman GF/F filters (Piscataway, NJ, USA), stored in Histoprep tissue capsules (Fisher Scientific, Waltham, MA, USA), and flash frozen in liquid nitrogen until processing. For processing, each sample was extracted in a test tube with $7 \mathrm{ml}$ of $90 \%$ acetone for approximately $21-24 \mathrm{~h}$ in a dark freezer. Chlorophyll $a$ fluorescence was then measured using a Turner Model 10-AU fluorometer (Sunnyvale, CA, USA) according to the method of Welschmeyer (1994).

\section{Dissolved inorganic nutrients}

Samples for nutrient analyses were collected by filtering water through $0.2 \mu \mathrm{m}$ capsule filters (Pall 12140, (Port Washington, NY, USA) using a peristaltic pump. The filtrate was collected and immediately frozen until analysis at the University of Maryland Center for Environmental Science. The nutrients measured and their associated detection limits (in parentheses) included ammonium $(0.21 \mu \mathrm{M})$, nitrite $(0.03 \mu \mathrm{M})$, nitrate +nitrite $(0.01 \mu \mathrm{M})$, phosphate $(0.02 \mu \mathrm{M})$, and silicate $(0.18$ $\mu \mathrm{M})$. Analyses were performed using a modified version of the method in the Chesapeake Biological Laboratory's Technical Report Series No. 158-97 (Keefe et al. 2004).

\section{Particulate organic carbon and nitrogen (POC and PON)}

POC and PON levels were measured through August 2007. Whatman GF/F filters were pre-combusted in a muffle furnace at $450^{\circ} \mathrm{C}$ for $4-6 \mathrm{~h}$ prior to collecting samples. Water samples were then filtered ( $<5 \mathrm{~mm}$ Hg negative pressure) onto the GF/F filters, and frozen until analysis. Prior to analysis, filters were dried at $50^{\circ} \mathrm{C}$ overnight in the laboratory. Once dried, they were taken to Horn Point Laboratory for final processing. The filters were put in a desiccator, fumed with $\mathrm{HCl}$ to remove the inorganic carbon, and re-dried. Samples were then analyzed with an Exeter Analytical, Inc. CE-440 Elemental Analyzer (Buckhurst Hill, UK) following methods in the Horn Point Laboratory Standard Operating Procedures.

\section{Results}

We sampled every 2 weeks at five stations normal to the coast and gently sloped from $7 \mathrm{~m}$ to $32 \mathrm{~m}$ (Figure 1). Shallow stations were well mixed to the bottom throughout the year. Stations 4 and 5 became stratified during the period from July to October, when primary productivity was highest. We conducted detailed phytoplankton microscopic analyses at the shallowest station (Station 1) and offshore Station 5 for 1 year. During the study, measurements of physical and chemical characteristics of these sites were made for later interpretations of coincident biomass and biodiversity observations.

\section{Physical parameters}

Our two shallow inshore stations were generally well mixed to the bottom throughout the year and showed little 
Table 3 Phytoplankton identified at Stations 1 and 5 from November 2006 to December 2007.

\section{Diatoms}

Achnanthes sp.

Actinoptychus senarius (Ehrenberg)

Asterionella glacialis (Castracane) Round

Bacillaria paxillifera (Mueller) Hendey

Bacteriastrum deliculatum Cleve

Biddulphia alternans (Bailey) Van Heurck

Cerataulina pelagic (Cleve) Hendey

Chaetoceros sp.

Chaetoceros aequatorialis Cleve

Chaetoceros affinis Launder

Chaetoceros compressus Lauder

Chaetoceros costatus Pavillard

Chaetoceros curvisetus Cleve

Chaetoceros danicus Cleve

Chaetoceros debilis Cleve

Chaetoceros decipiens Cleve

Chaetoceros diadema (Ehrenberg) Gran

Chaetoceros didymus Ehrenberg

Chaetoceros lorenzianus Grunow

Chaetoceros socialis Lauder

Corethron criophilum Castracane

Coscinodiscus radiates Ehrenberg

Coscinodiscus wailesii Gran et Angst

Cyclotella litoralis Lange et Syvertsen

Dactyliosolen fragilissimus (Bergon) Hasle

Detonula sp.

Ditylum brightwellii (West) Grunow

Eucampia zodiacus Ehrenberg

Fragilaria sp.

Gonioceros sp. H. et M. Peragallo

Guinardia flaccida (Castracane) H. Peragallo

Guinardia striata (Stolterforth) Hasle

Heliotheca sp. Yankovskii

Dinoflagellates

Dinoflagellates $<20 \mu \mathrm{m}$

Gonyaulax sp. Diesing

Gymnodinium sp. Stein

Gyrodinium sp. Kofoid et Swezy

Katodinium rotundatum (Lohmann) Fott

Amphidinium sp. Claparède et Lachmann

Unknown \#3014

Unknown \#3023

Dinoflagellates 20-40 $\mu \mathrm{m}$

Amphidinium sp. Claparède et Lachmann

Amphidinium sphenoides Wülff

Gonyaulax polygramma Stein

Gonyaulax spinifera (Claparède et Lachmann) Diesing

Gymnodinium sp. Stein

Gyrodinium sp. Kofoid et Swezy

Prorocentrum gracile Schütt

Protoperidinium divergens Ehrenberg

Dinoflagellates $>40 \mu \mathrm{m}$

Alexandrium sp. Halim

Ceratium fusus (Ehrenberg) Dujardin

Ceratium lineatum (Ehrenberg) Cleve

Ceratium macroceros (Ehrenberg) Vanhöffen

Ceratium trichoceros (Ehrenberg) Kofoid

Ceratium tripos (Müller) Nitzsch

Dinophysis acuminata Claparède et Lachmann

Dinophysis dens Pavillard

Dinophysis norvegica Claparède et Lachmann

Gymnodinium sp.

Prorocentrum micans Ehrenberg
Hemiaulus sinensis Greville

Leptocylindricus minimus Gran

Lioloma c.f. pacificum (Cupp) Hasle

Melosira sp. Agardh

Navicula transitans Cleve

Nitzschia longissima (Brebisson) Ralfs

Odontella mobilensis (Bailey) Grunow

Odontella sinensis (Greville) Grunow

Paralia sulcata (Ehrenberg) Cleve

Plagiogramma sp. Greville

Pleurosigma normanii Ralfs

Pseudo-nitzschia multiseries (Hasle) Hasle

Pseudo-nitzschia pseudodelicatissima (Hasle) Hasle

Pseudo-nitzschia pungens (Grunow ex Cleve) Hasle

Rhabdonema sp. Kütz

Rhaphoneis amphiceros Ehrenberg

Rhizosolenia sp. (Ehrenberg) Brightwell

Rhizosolenia alata Brightwell

Rhizosolenia imbricate Brightwell

Rhizosolenia setigera Brightwell

Rhizosolenia styliformis Brightwell

Skeletonema costatum (Greville) Cleve

Thalassionema nitzschioides (Grunow) Mereschkowsky

Thalassiosira sp. Cleve

Thalassiosira $(20 \mu \mathrm{m})$

Thalassiosira $(30 \mu \mathrm{m})$

Thalassiosira $(40 \mu \mathrm{m})$

Thalassiosira $(50 \mu \mathrm{m})$

Thalassiothrix sp.

Unknown pennate \#1024

Unknown pennate \#1037

Unknown centric \#1040

Unknown pennate \#1061

Unknown \#3027

Unknown \#3033

Unknown \#3035

Unknown \#3036

Unknown \#3039

Unknown \#3045

Protoperidinium pellucidum (Bergh) Schütt

Pyrophacus horologicum Stein

Scripsiella trochoidea (Stein) Loeblich

Unknown \#3015

Unknown \#3016

Unknown \#3018

Unknown \#3021

Unknown \#3053

Prorocentrum scutellum Schroder

Protoperidinium sp.

Protoperidinium depressum (Bailey) Balech

Protoperidinium pallidum (Ostenfeld) Balech

Unknown \#3040

Unknown \#3042

Unknown \#3044

Unknown \#3046

Unknown \#3051

Unknown \#3056

See Table 1 for station locations. 
variability, whereas the outer shelf stations generally stratified during the summer and early autumn (Figure 2). Water temperature in the region ranged from $\sim 5^{\circ} \mathrm{C}$ in March to $\sim 26^{\circ} \mathrm{C}$ in September during the 2-year period. Salinity ranged from 30.76 to 33.55 during the study period, and we observed a gradient of higher salinity with distance offshore.

\section{Irradiance}

Photosynthetically available radiation reached the bottom at the inshore stations (Stations 1 and 2), and phytoplankton generally did not develop a depth-related chlorophyll maximum because the mixed layers reached down to the bottom (data not shown). Station 5 appeared to develop a chlorophyll maximum that was associated with low light levels, low micronutrients, and punctuated periods of stratification, especially during spring and fall blooms.
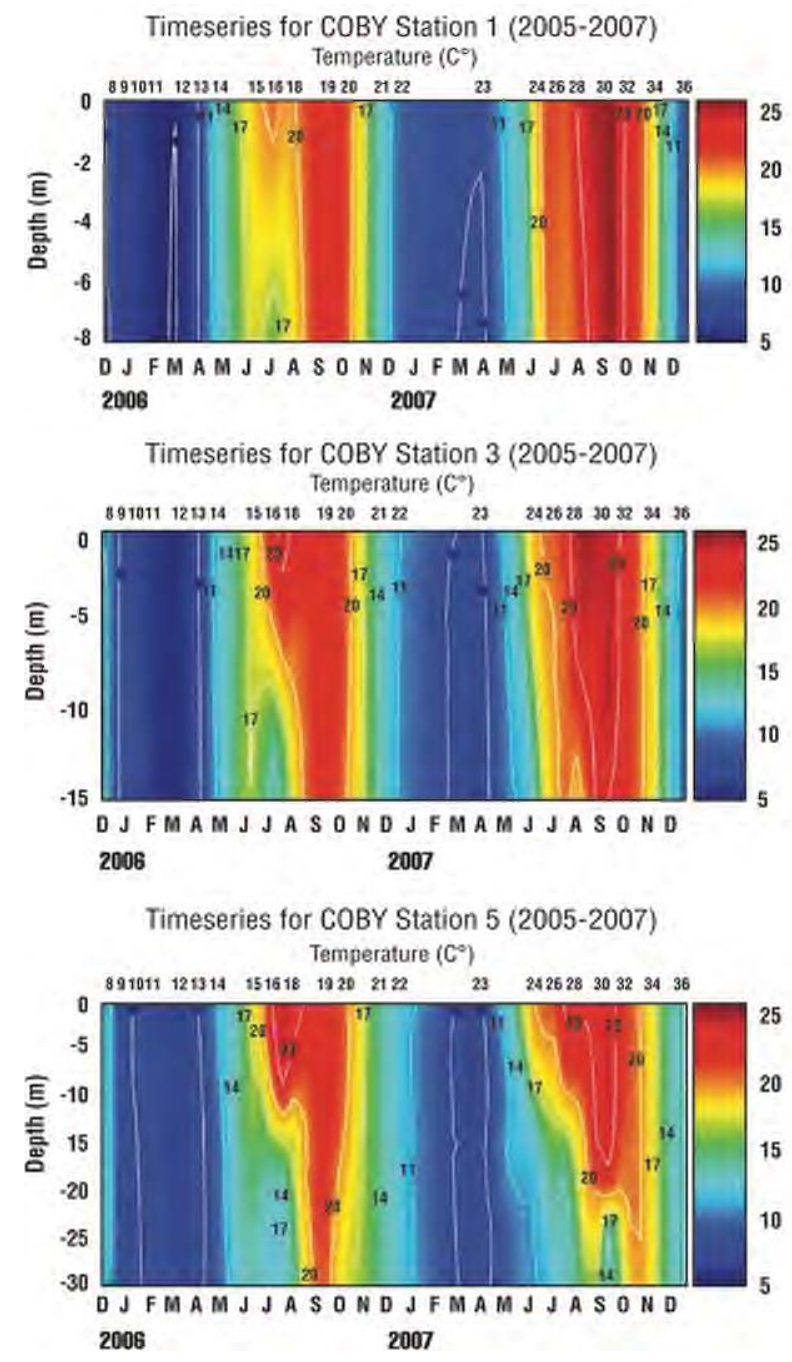

\section{Fluorometric chlorophyll a}

Fluorometric chlorophyll $a$ concentrations ranged from 0.2 $\mu \mathrm{g}^{-1}$ to $15.5 \mu \mathrm{g}^{-1}$ over the course of the time series. Values were generally highest at Station 1 and declined with distance from shore (Figure 3). Mean surface chlorophyll $a$ concentrations ranged from $1.6( \pm 1.3) \mu \mathrm{g} \mathrm{l}^{-1}$ at Station 5 to $4.6( \pm 3.0)$ $\mu \mathrm{g}^{-1}$ at Station 1 . When examining the time series over the 2-year period, it was evident that spikes in chlorophyll $a$ were more common inshore throughout the year. It was also common to observe chlorophyll $a$ maxima near the bottom, especially at Station 5, where the bottom chlorophyll $a$ concentration was over 29 times higher than the surface concentration in September 2007.

During the spring bloom, we repeatedly observed a stratified pattern relating to temperature and salinity. Chlorophyll $a$ values were higher at near-bottom depths. Nutrient concentrations were relatively high throughout
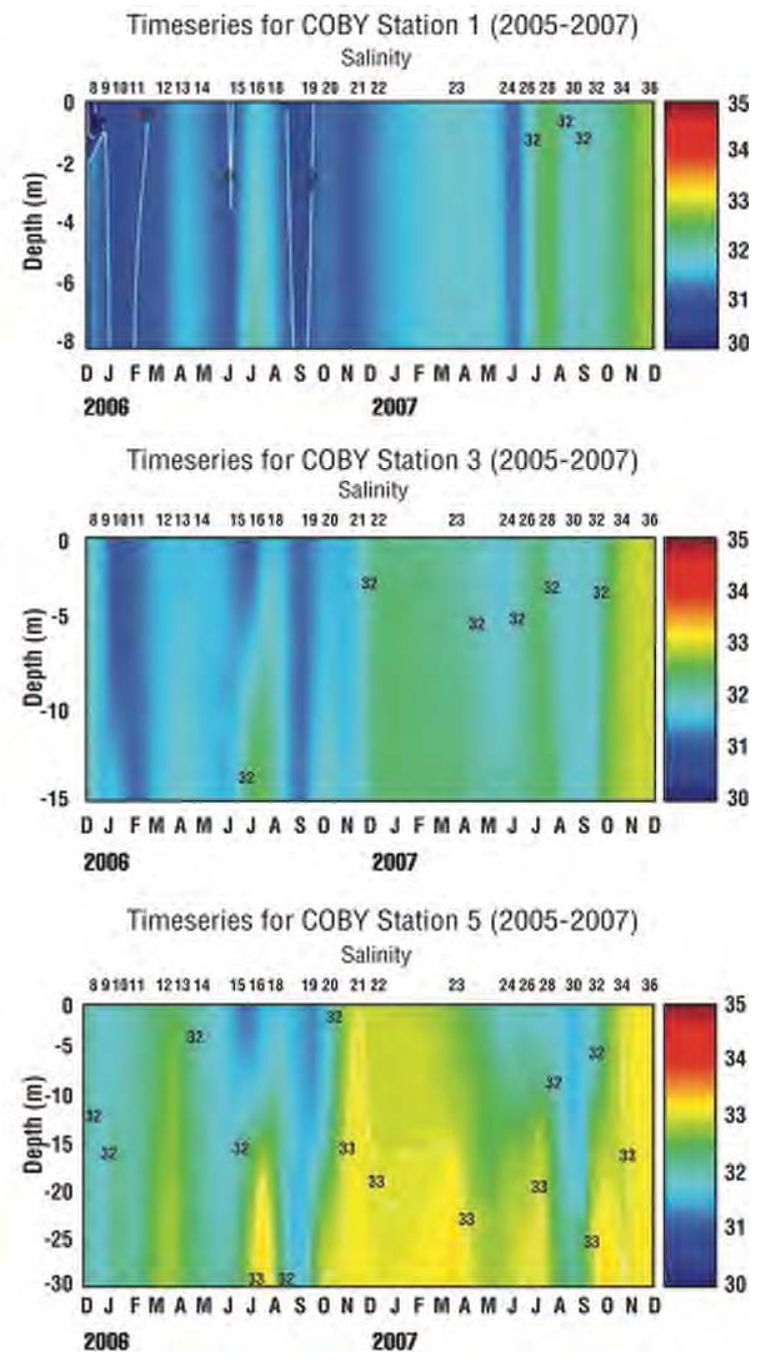

Figure 2 Temperature and salinity time-series data for Stations 1, 3, and 5. Values are from continuous conductivity, temperature and depth (CTD) samples and binned at $0.5 \mathrm{~m}$ intervals. Values represent the median between the upcast and the downcast of the CTD. See Table 1 for station information. 

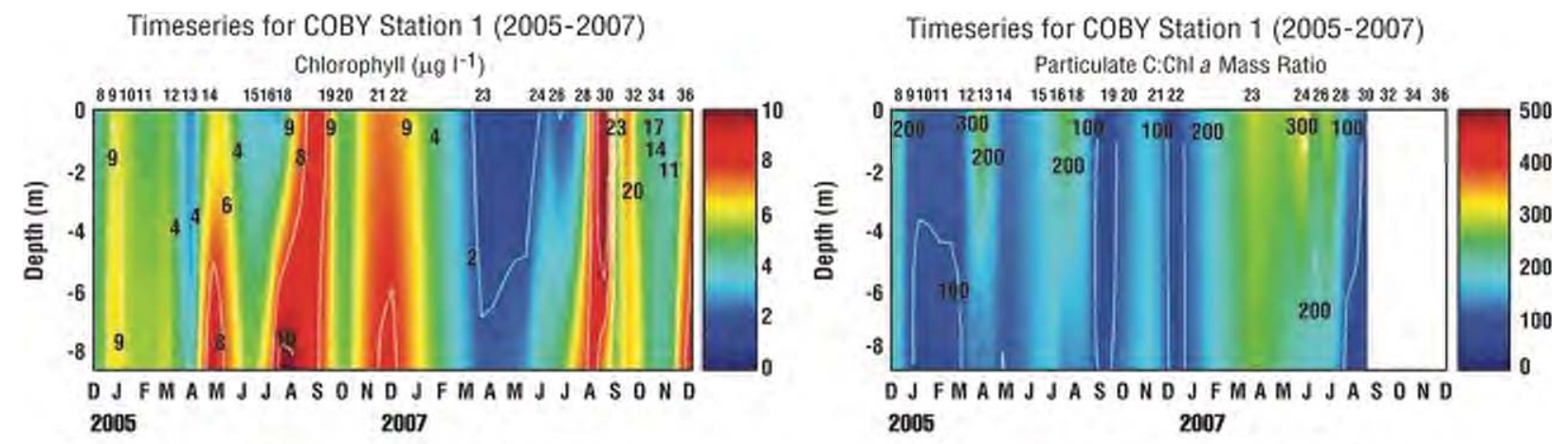

Timeseries for COBY Station 3 (2005-2007)

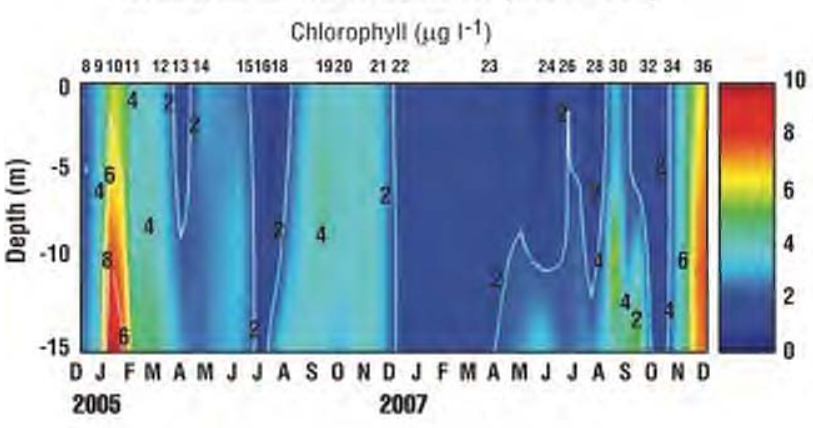

Timeseries for COBY Station 5 (2005-2007)

Chlorophyll ( $\mu \mathrm{g} \mathrm{I}^{-1}$ )

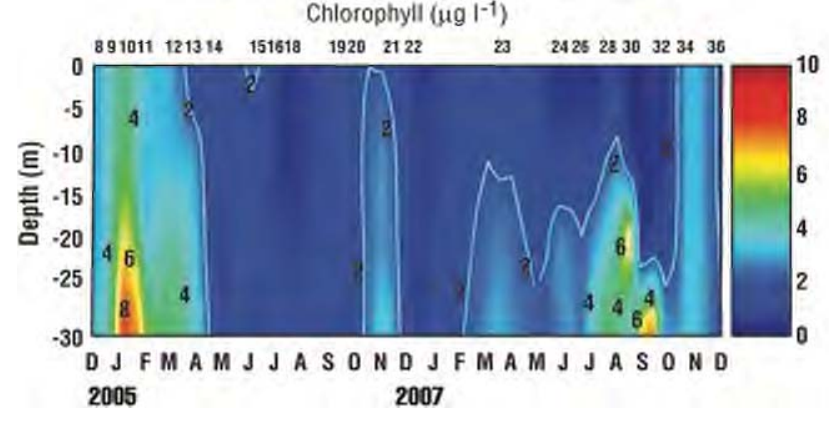

Timeseries for COBY Station 3 (2005-2007)

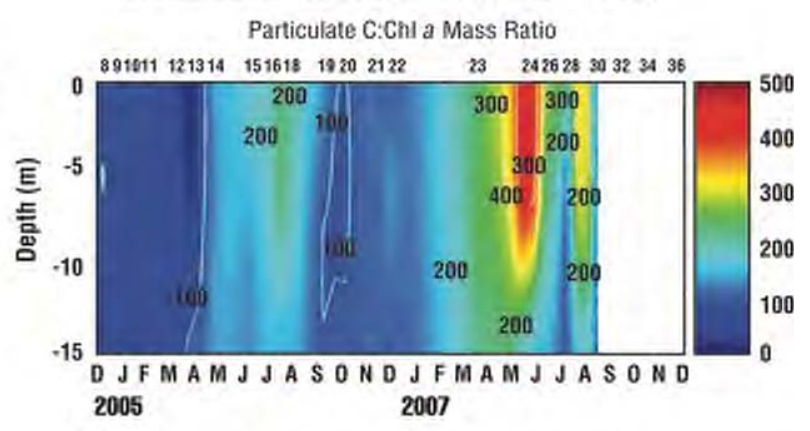

Timeseries for COBY Station 5 (2005-2007)

Particulate C:Chl a Mass Ratio

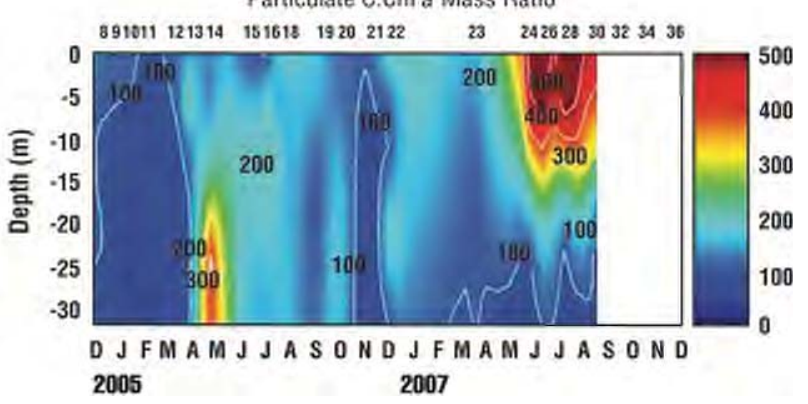

Figure 3 Average fluorometric chlorophyll $a$ concentrations and carbon to chlorophyll $a$ ratio (C:Chl $a$ ) time-series plots for Stations 1, 3, and $5(\mathrm{n}=3)$. See Table 1 for station information.

the water column during this period of time. It appeared that Station 1 was able to maintain a critical biomass for a longer period of time, probably due to less light limitation. Highest average concentrations of chlorophyll $a$ typically occurred in the winter, followed by the autumn bloom (Table 2).

In contrast, we observed short bursts of certain taxa that may have been due to changes in water mass, upwelling/ downwelling events, or grazing. The increases in phytoplankton biomass occurred in response to favorable upwelling conditions that occurred in small-scale patches along the coast (Wong 2002). It was difficult to determine whether these conditions were favorable because of nutrient concentrations or light-availability conditions. Nevertheless, we postulate that a mixture of $\mathrm{r}$ - and k-selected types of phytoplankton took advantage of these vertical mixing events (Silva et al. 2009).

\section{Particulate organic carbon and nitrogen (POC and PON)}

Throughout the study, POC ranged from $54 \mu \mathrm{g} \mathrm{l^{-1 }}$ (Station 5) to $1563 \mu \mathrm{g} \mathrm{l}^{-1}$ (Station 1), and PON ranged from $10 \mu \mathrm{g}$ $\mathrm{l}^{-1}$ (Station 5) to $221 \mu \mathrm{g} \mathrm{l}^{-1}$ (Station 1). Both POC and PON values typically decreased with distance from shore. POC values for Station 1 were highest during summer months at bottom depths but peaked in November 2006 at all depths. In November 2006, a concentration of $1563 \mu \mathrm{g} \mathrm{l^{-1 }}$ POC was measured at $7 \mathrm{~m}$ depth. At this inshore station, POC was lowest at the surface, and did not track any seasonal pattern. No consistent seasonal or vertical patterns for POC were evident at Station 5, but values ranged through an order of magnitude from $54 \mu \mathrm{g} \mathrm{l}^{-1}$ to $534 \mu \mathrm{g}^{-1}$. PON was typically highest at bottom depths at Station 1, and ranged from 47-221 $\mu \mathrm{g} \mathrm{l}^{-1}$. At the offshore station, PON ranged from 10 to $88 \mu \mathrm{g} \mathrm{l}^{-1}$, but no 
vertical pattern was apparent. No seasonal patterns for PON were observed at any station.

The particulate C:N ratio ranged from 4.13 to 18.38 . The C:N ratio of particulates was less than the Redfield Ratio of $106: 16$ in $58 \%$ of samples $(n=277)$. The particulate organic C:N ratio was less than the Redfield Ratio of 106:16 in 44\% of the samples from Station $1(n=57)$ and in $67 \%$ of samples from Station $5(n=83)$. This may indicate that there was a significant amount of detritus in the area, which is considered labile. In addition, we observed a significant portion of detrital absorption (T.A. Moisan, data not shown). POC values were used to calculate the carbon to chlorophyll $a(\mathrm{C}: \mathrm{chl} a)$ mass ratio. Patterns in the $\mathrm{C}: \mathrm{chl} a$ ratio were similar across stations, but the values were more variable at stations further offshore, where short-duration, high intensity peaks occurred (Figure 3). During the late 2007 peak at Station 5, the C:chl $a$ ratio was over 500 . No clear seasonal, annual, or depth trends in C:chl $a$ ratios were apparent at any station. However, a multiple linear regression indicated that the C:chl $a$ was significantly $\left(\mathrm{R}^{2}=0.86\right)$ associated with detritus and temperature, based on detrital absorption $(\mathrm{p}<0.001)$ and temperature data $(\mathrm{p}=0.005)$.

\section{Dissolved inorganic nutrients}

Throughout the study, we measured micronutrients, including nitrate, phosphate, silicate, and ammonium, at select stations. Individual nutrients were highest in concentration at inshore stations and episodes of elevated concentration were consistently observed, as seen in the examples shown in Figures 4 and 5. Nitrate, phosphate, and silicate had punctuated periods of elevated concentration at inshore stations, which dissipated with distance from shore. Nitrate peaked throughout the water column in December 2006 and November 2007. The mean
Timeseries for COBY Station 1 (2005-2007)

$$
\text { Nitrate }(\mu \mathrm{m})
$$

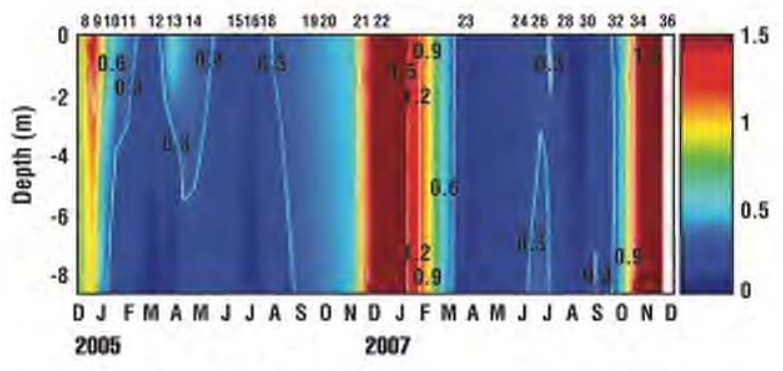

Timeseries for COBY Station 3 (2005-2007)

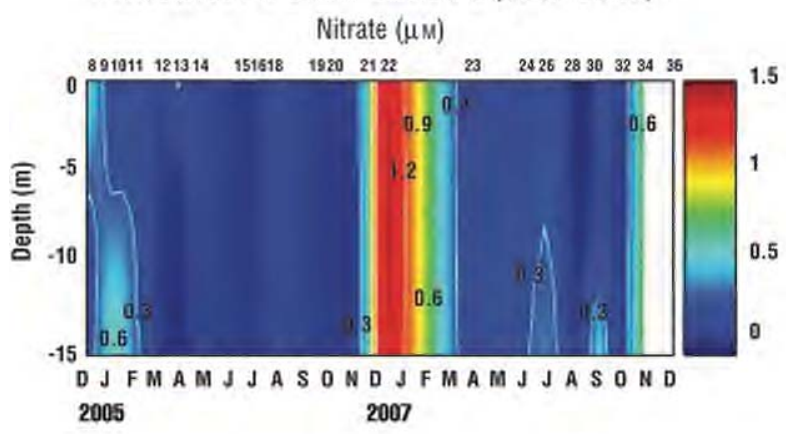

Timeseries for COBY Station 5 (2005-2007)

Nitrate $(\mu \mathrm{m})$

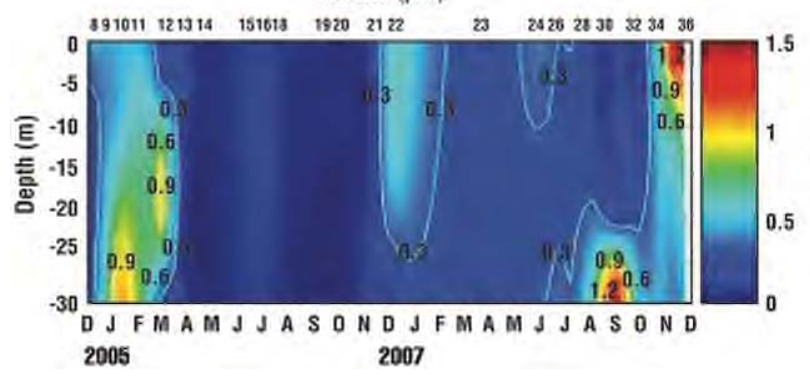

Timeseries for COBY Station 1 (2005-2007)

Phosphate $(\mu \mathrm{m})$

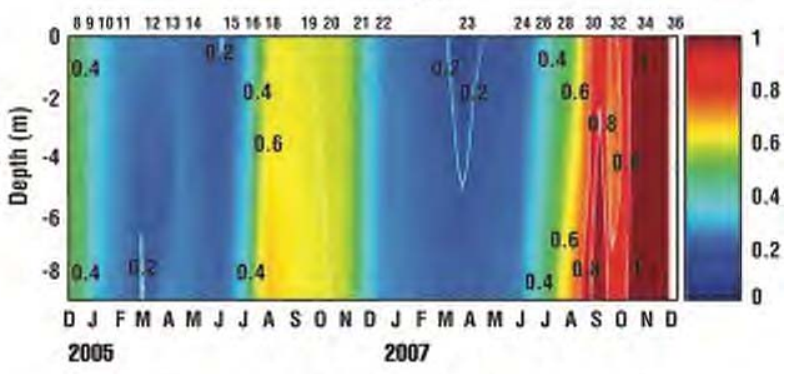

Timeseries for COBY Station 3 (2005-2007)

Phosphate $(\mu \mathrm{M})$

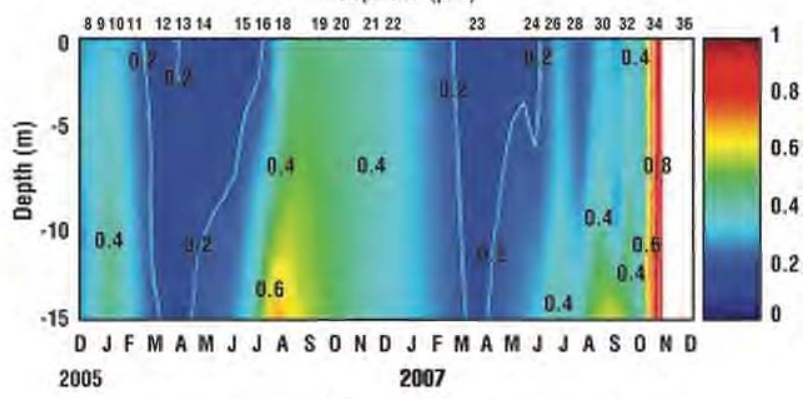

Timeseries for COBY Station 5 (2005-2007)

Phosphate ( $\mu$ m)

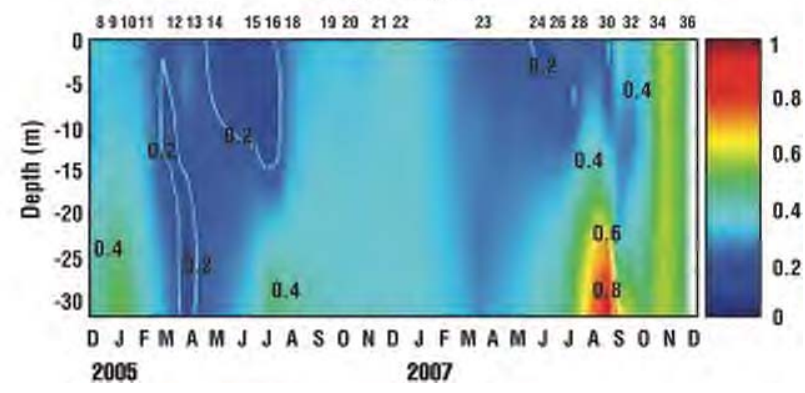

Figure 4 Micromolar concentrations of nitrate (left) and phosphate (right) at Stations 1, 3, and $5(\mathrm{n}=3)$. See Table 1 for station information. 
Timeseries for COBY Station 3 (2005-2007) Dissolved N:P Molar Ratio

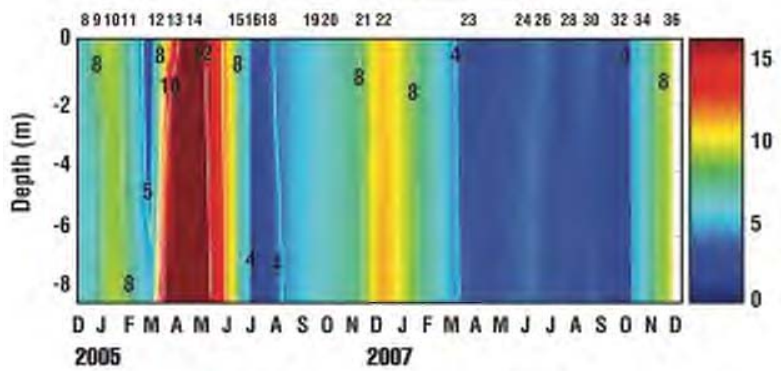

Timeseries for COBY Station 3 (2005-2007) Dissolved N:P Molar Ratio

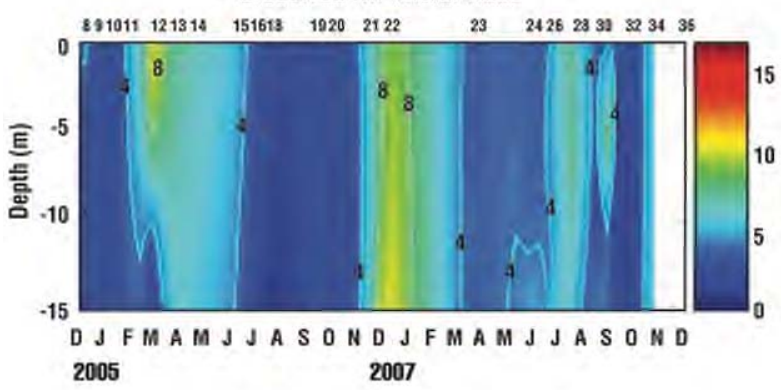

Timeseries for COBY Station 5 (2005-2007)

Dissolved N:P Molar Ratio

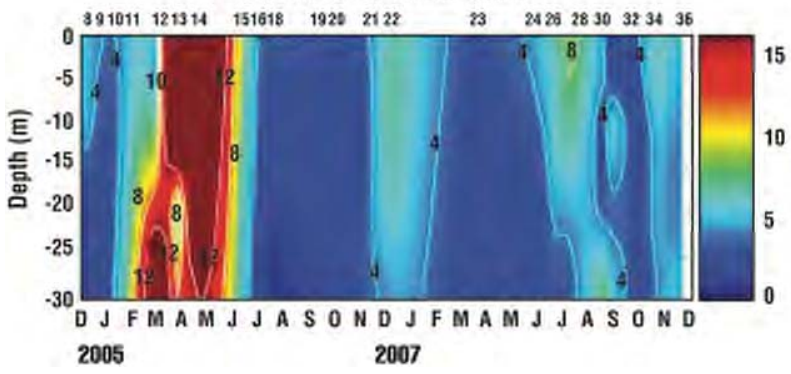

Timeseries for COBY Station 3 (2005-2007)

Dissolved Si:P Molar Ratio

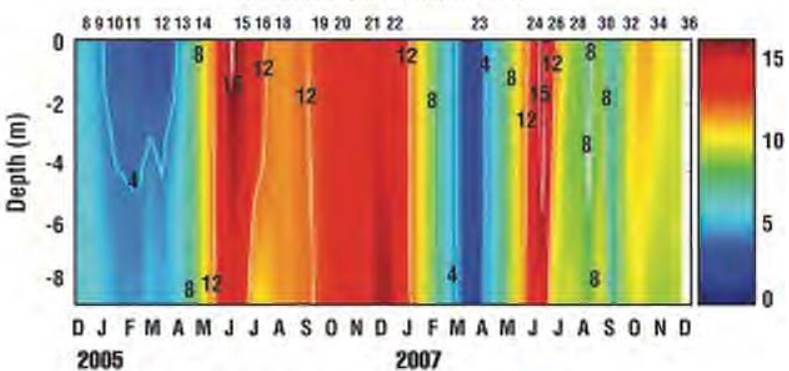

Timeseries for COBY Station 3 (2005-2007)

Dissolved Si:P Molar Ratio

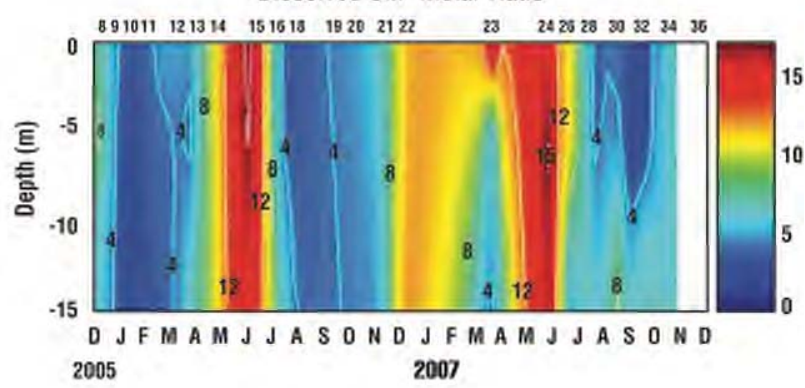

Timeseries for COBY Station 5 (2005-2007)

Dissolved Si:P Molar Ratio

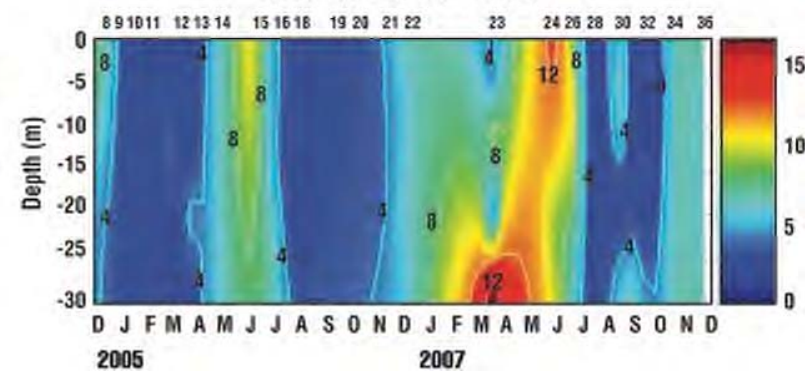

Figure 5 Molar ratios of dissolved nutrients at Stations 1, 3, and $5(\mathrm{n}=3)$. See Table 1 for station information.

nitrate concentration in December 2006 in the water column at Station 1 was $2.21 \mu \mathrm{M}( \pm 0.078, \mathrm{n}=3)$, and decreased offshore to a low of $0.46 \mu \mathrm{M}( \pm 0.261, \mathrm{n} 5)$ at Station 5. In November 2007, the mean nitrate concentration reached 3.07 $\mu \mathrm{M}$ at Station $1( \pm 0.261, n=3)$. Elevated spikes of phosphate and silicate were observed during July through November 2006 and were most evident at Stations 1 and 2. A second, more intense episode of phosphate and silicate elevation was noted in the autumn of 2007 at Station 1. The phosphate and silicate spikes was also noted at other stations, but occurred later in the season.

Molar ratios of nitrogen, phosphate, and silicate indicated that this region is often nitrogen-limited (Figure 5). The nitrogen to phosphate molar ratio $(\mathrm{N}: \mathrm{P})$ typically remained less than the Redfield ratio (C:Si:N:P=106:15:16:1) at all stations. Nitrogen was a limiting nutrient in 97\% $(n=62)$ and $95 \%(n=86)$ of samples at Stations 1 and 5, respectively. Silicate also limited the growth of diatoms, as the Si:P ratio was less than $15: 1$ in $99 \%$ of samples $(n=89)$; the silicate to phosphate (Si:P) ratio was highest at Station 1 and decreased offshore.

\section{Phytoplankton taxonomic composition}

Diatoms made up the majority of the phytoplankton biomass based on chlorophyll $a$, and typically accounted for about 40$50 \%$ of the total phytoplankton community. Phytoplankton concentrations ranged from 118 cells $\mathrm{ml}^{-1}$ (November) to 6104 cells $\mathrm{ml}^{-1}$ (July) at Station 1 . At Station 5, the range was roughly $<100$ cells $\mathrm{ml}^{-1}$ (October) to 10,856 cells $\mathrm{ml}^{-1}$ (September). The phytoplankton community consisted of a range of taxa from small flagellates $(-2.5-5.0 \mu \mathrm{m})$ to large diatoms $(>200 \mu \mathrm{m})$ to colonial Phaeocystis. Together, the diatoms Skeletonema costatum, Chaetoceros, Pseudo-nitzschia, Thalassiosira, Asterionella glacialis, and Rhizosolenia dominated throughout the study. 
In contrast, dinoflagellates occurred at lower abundances and were most abundant in summer when waters were stratified (Figure 6). Dinoflagellates were common at the surface in late July and late August, with over 700 and 900 cells ml-1 , respectively. Dinoflagellates were most abundant at Station 5 during mid-June and ranged from 16 cells $\mathrm{ml}^{-1}$ at the surface to 848 cells $\mathrm{ml}^{-1}$ (Figure 6). Throughout the year, ambient dinoflagellate concentrations were generally $<100$ cells $\mathrm{ml}^{-1}$. Phaeocystis colonies were present in the mid- to late summer. Cyanobacteria were at their highest concentrations in summer months and were associated with warm water (Moisan et al. 2010).

\section{Temporal distribution of the phytoplankton assemblage}

Individual phytoplankton taxon distribution was patchy both spatially and temporally. It was common to see a short burst of one species that would almost disappear from the assemblage by the next cruise ( $\sim 2$ weeks later). There was tremendous variability in assemblage compositions by depth that resulted in high phytoplankton diversity. We saw short peaks of high concentration for certain taxa that may have been due to changes in water mass, upwelling/downwelling events, or grazing (J. Ambler, unpublished data). We observed favorable upwelling conditions, which occurred along the coast in small-scale patches (Wong 2002).

\section{Patterns of diatom diversity}

Throughout our study, we noted minor spatial and temporal variations in the diversity of the diatoms when comparing the assemblages at the inshore and offshore stations. Diatoms were classified down to the genus level and Shannon-Weaver diversity indices $\left(\mathrm{H}^{\prime}\right)$ were calculated for each sampling date (Shannon and Weaver 1949, Pielou 1966). Diatom diversity ranged from 0.343 to 1.487 at the inshore station and from 0.293 to 0.906 at the offshore station. Average diversity was lowest in the spring and autumn, when blooms typically occurred (Table 4). We chose several numerically abundant phytoplankton genera and present their seasonal distribution
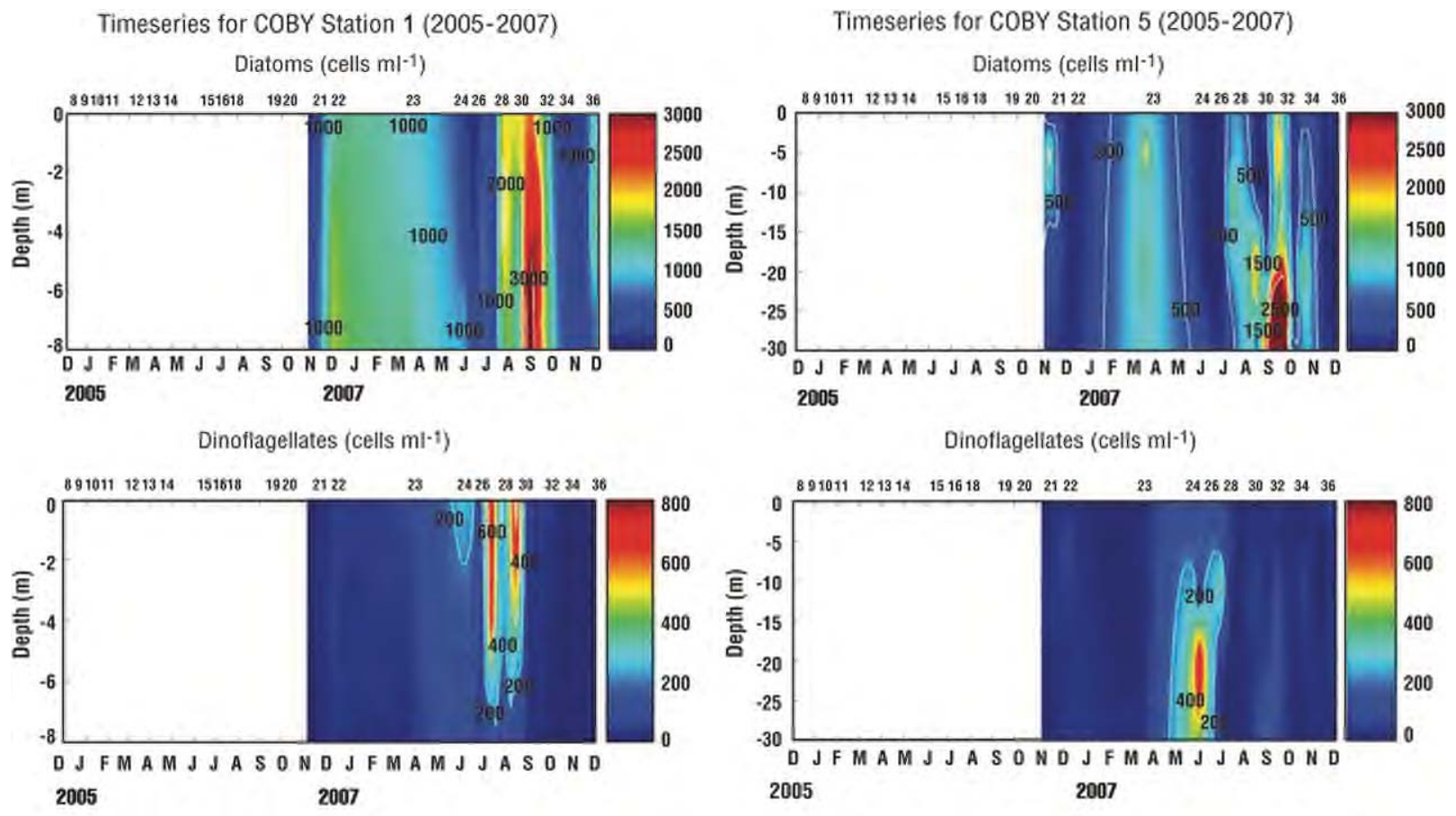

Flagellates (cells ml-1)
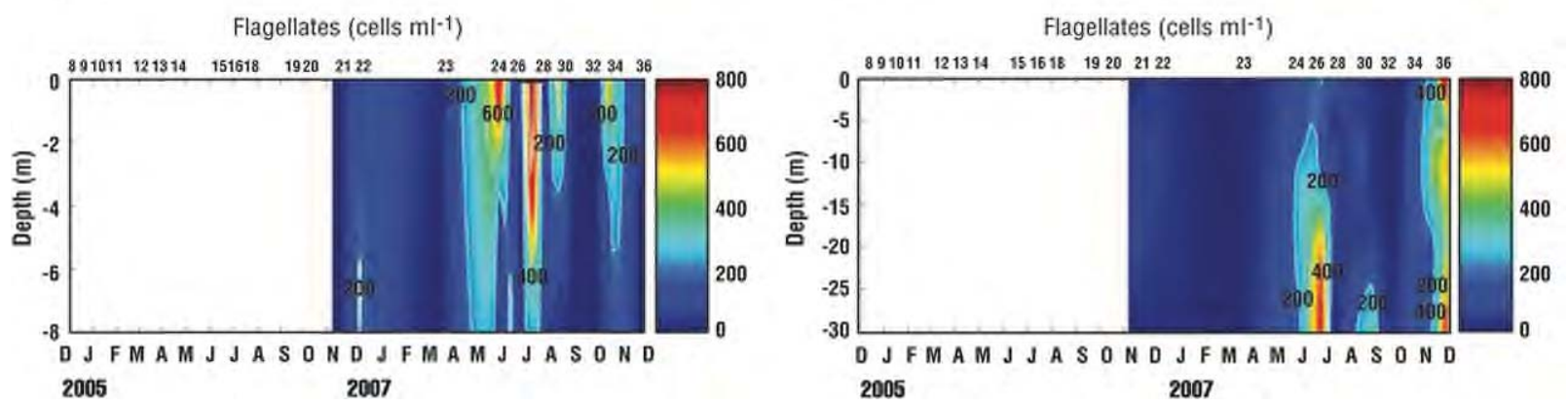

Figure 6 Patterns of diatom, dinoflagellate, and flagellate cell concentrations at Stations 1 and 5. Note that these microscopic analyses began in November 2006. Coefficient of variation for each sample was $<20 \%$. See Table 1 for station information. 
Table 4 Seasonal mean diatom genus diversity (Shannon Weaver index) ( \pm SD).

\begin{tabular}{lllll}
\hline & Winter & Spring & Summer & Autumn \\
\hline Station 1 & $1.203( \pm 0.402)$ & $0.568( \pm 0.110)$ & $0.804( \pm 0.149)$ & $0.753( \pm 0.206)$ \\
Station 5 & $0.819( \pm 0.028)$ & $0.538( \pm 0.107)$ & $0.671( \pm 0.237)$ & $0.595( \pm 0.191)$ \\
\hline
\end{tabular}

here. The chosen genera had relatively high abundances and had unique and episodic temporal patterns throughout the year. Data for Thalassiosira, Pseudo-nitzschia, Rhizosolenia, are depicted in Figure 7. The appearances of taxa were mixed throughout the water and appeared to persist for more than 2 weeks for each taxon. We also observed temporal patchiness in other genera, such as Chaetoceros, Skeletonema, and colonial Phaeocystis (Table 5).

\section{Discussion}

There has been an increasing emphasis on assembling long-term time-series data, including Long-Term
Ecosystem Research (LTER), CalCoFI (California Cooperative Oceanic Fisheries Investigations), BATS, HOTs, MOBY (Marine Optical Buoy), and NASA satellite products because they are ideally suited for investigations that detect subtle habitat changes, irregularly spaced, stochastic events, and complex, interdependent ecological phenomena that affect biogeochemical cycles in the world ocean (Karl et al. 2001). The net flux of inorganic nutrients and organic carbon through the coastal zone is controlled by diverse biogeochemical processes that occur within a coupled web of ecological subsystems. We focus in this paper on a 2-year time series of chlorophyll $a$, physical parameters, and nutrients, with 1 year of detailed microscopy of taxon composition.
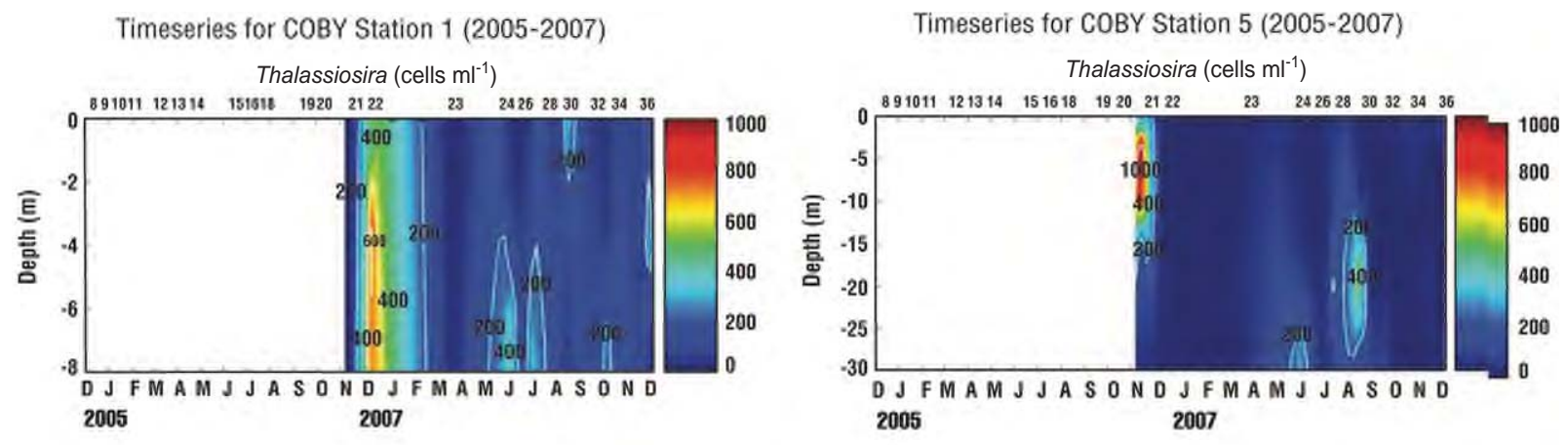

Pseudo-nitzschia (cells $\mathrm{ml}^{-1}$ )
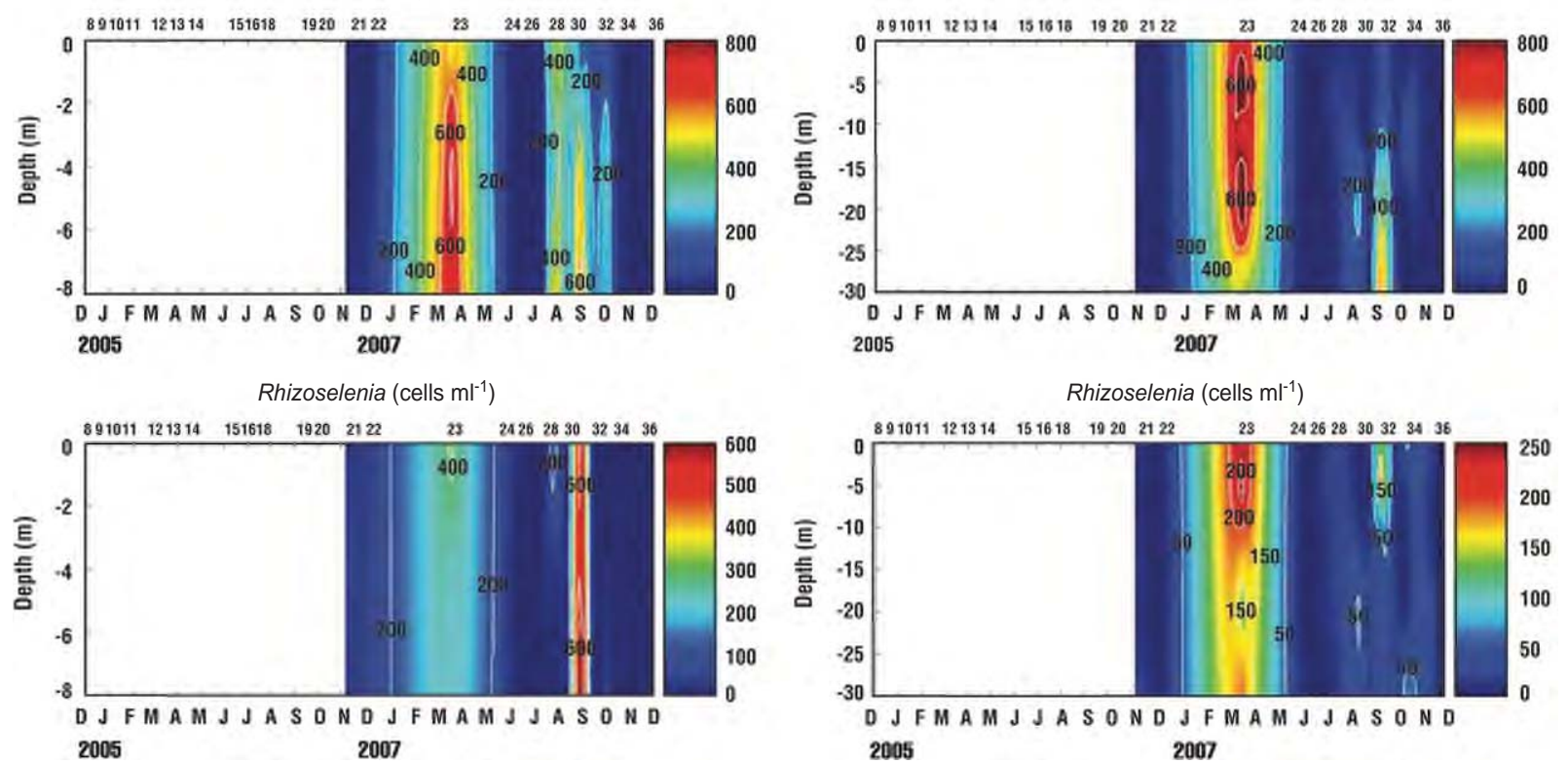

Figure 7 Spatial distribution of Thalassiosira, Pseudo-nitzschia, and Rhizosolenia. Seasonal trends in cell concentrations at Station 1 (left) and Station 5 (right). Coefficient of variation for each sample was $<20 \%$. See Table 1 for station information. 
Table 5 Abundances of dominant genera from November 2006 through December 2007 and peak depths.

\begin{tabular}{|c|c|c|c|c|c|}
\hline Genus & Station & Peak months & $\begin{array}{l}\text { Peak } \\
\text { depth (m) }\end{array}$ & $\begin{array}{l}\text { Cell count at } \\
\text { Peak depth } \\
\left(\text { cells } \mathrm{ml}^{-1} \text { ) }\right.\end{array}$ & $\begin{array}{l}\text { Mean cell count, } \\
\text { all depths sampled } \\
\left(\text { cells } \mathrm{ml}^{-1}\right)\end{array}$ \\
\hline \multirow[t]{2}{*}{ Thalassiosira } & 1 & December (2006) & 4 & 883 & $655( \pm 276)$ \\
\hline & 5 & November (2006) & 5 & 1580 & $355( \pm 686)$ \\
\hline \multirow[t]{5}{*}{ Pseudo-nitzschia } & 1 & March & 4 & 873 & $691( \pm 225)$ \\
\hline & & August & 7 & 608 & $456( \pm 230)$ \\
\hline & & September & 7 & 696 & $448( \pm 337)$ \\
\hline & 5 & March & 5 & 1285 & $756( \pm 407)$ \\
\hline & & September & 29 & 656 & $307( \pm 249)$ \\
\hline \multirow[t]{4}{*}{ Rhizosolenia } & 1 & March & 0 & 348 & $255( \pm 81)$ \\
\hline & & September & 7 & 920 & $715( \pm 197)$ \\
\hline & 5 & March & 5 & 275 & $204( \pm 55)$ \\
\hline & & September & 5 & 216 & $96( \pm 76)$ \\
\hline \multirow[t]{4}{*}{ Chaetoceros } & 1 & August & 4 & 1400 & $928( \pm 586)$ \\
\hline & 5 & July & 10 & 960 & $435( \pm 401)$ \\
\hline & & September & 5 & 896 & $555( \pm 244)$ \\
\hline & & October & 20 & 1032 & $454( \pm 381)$ \\
\hline \multirow[t]{3}{*}{ Skeletonema } & 1 & December (2006) & 7 & 787 & $569( \pm 201)$ \\
\hline & & September & 4 & 2480 & $1803( \pm 628)$ \\
\hline & 5 & September & 29 & 6136 & $1578( \pm 2555)$ \\
\hline \multirow[t]{4}{*}{ Phaeocystis } & 1 & July & 4 & 5112 & $2403( \pm 2570)$ \\
\hline & 5 & November (2006) & 0 & 6967 & $3025( \pm 2571)$ \\
\hline & & July & 20 & 1848 & $566( \pm 834)$ \\
\hline & & September & 29 & 2856 & $571( \pm 1277)$ \\
\hline
\end{tabular}

Cell concentrations had a coefficient of variation of $<20 \%$ where $n=19$ depths. See Table 1 for station information.

A limited number of studies have characterized the phytoplankton assemblage in Virginian coastal waters (Marshall 1991, Malone et al. 1991). The Virginian coastal ocean phytoplankton assemblage is considered diverse, often dominated by small, chain-forming diatoms and a picoplankton component of Cyanobacteria and chlorophyceans (Malone et al. 1991). The annual cycle of phytoplankton includes a peak in the spring, which is usually dominated by diatoms. By late spring, phytoplankters become nutrient-limited by either nitrate or phosphate and flagellates often dominate (Fisher et al. 1999). A bloom smaller in magnitude often occurs in the autumn and is different in composition from the spring bloom (Marshall 1991). We found a diverse assemblage consisting of 116 phytoplankton species dominated by different diatoms during the year, with pulses of flagellates during summer in response to localized increases in Cyanobacteria (Moisan et al. 2010).

The phytoplankton assemblage was diverse and phytoplankton succession was probably driven by a replacement of species by other species, as hypothesized by theories contributed by Smayda (1997, 1998). For example, we observed many patches of phytoplankton species over time that we believe were composed of opportunists that are able to take advantage of high nutrients in a mixed high-light environment. Assemblages were dominated by flagellates when nutrients were limiting in summer; heterotrophic flagellates are able to feed on Cyanobacteria (Moisan et al. 2010).

\section{Seasonal patterns in phytoplankton biomass and taxonomic composition}

We were able to monitor physical properties, as well as chlorophyll $a$ and POC consistently over the course of 2 years (Figures 2 and 3). In 2006, we found a weak winter/spring bloom, which was also confirmed by Ocean Color satellite imagery. In 2007, we were unable to capture the winter/spring bloom because of limited sampling opportunities, but satellite imagery indicated a stronger bloom, peaking in January and February. During both years (2006-2007), we observed a secondary bloom in the autumn, beginning in September and October in 2006 and 2007, respectively. Phytoplankton appeared to increase production in quick pulses in response to pulses in nitrate and phosphate, as shown by a great degree of variability in C:chl $a$ ratios (Figure 4). High C:chl $a$ ratios are probably representative of an association of detrital biomass and phytoplankton, as shown by the relatively high detrital matter to phytoplankton particle ratio (N. Ohi et al., unpublished data). It is likely that a portion of POC was contributed by detritus; we observed high detrital absorption in comparison to phytoplankton absorption (see Results).

It appears that the phytoplankton assemblage was able to acclimate to deep mixed layers because it was associated with deep euphotic zones that often reached the bottom at both stations, with a range of chlorophyll-specific absorption values [a*ph $(\lambda)$ associated with chromatic adaptation (T.A. Moisan, unpublished data)]. There was little relation between chlorophyll $a$ and nutrient ratios (Figure 5); the limiting nutrient in 
this region appeared to be nitrate. Based on nutrient profiles, we postulate at least two sources for nutrients. The higher concentrations and increased chlorophyll $a$ concentration at near-bottom depths of Station 5 led us to believe that there was a sediment-based flux of nutrients at this offshore station. However, the major nitrate spike in December 2006 and phosphate spike in July 2006, which were largest at Station 1 and decreased with distance from shore, indicate that a second source of nutrients may be terrestrially-based. Because Chincoteague Bay has such a low flushing rate, it is not likely that it is the source of these nutrients during periods of punctuated growth. N. Ohi (unpublished data) found a tight correlation between phosphate and optical properties during the time series described by inherent optical properties and bulk reflectance. It is likely that nutrients were replenished by longshore flow from large sources of estuarine water from Delaware Bay and possibly the Chesapeake Bay or upwelling events (A. Kumar, pers. communication).

\section{Diversity patterns of the phytoplankton assemblage in the coastal environment}

To quantify phytoplankton community diversity, we utilized the Shannon Weaver index, which is a commonly used metric in ecology. Because we relied heavily on preserved samples enumerated using contrast microscopy, in addition to epifluorescence, our analysis of size and taxonomic diversity is constrained to those forms that were well preserved and identifiable by light microscopy. Therefore, our Shannon Weaver index is most likely an underestimate of the diversity in our study area. It appeared that diversity indices were variable over the course of the year, with a decrease in diversity during the autumn bloom and greater diversity in the late winter/ early spring bloom. Additionally, we observed episodic peaks in certain taxa, which appeared to be associated with peaks in nutrients and possibly different water masses.

We present six different taxa, including Thalassiosira, Pseudo-nitzschia, Rhizosolenia, that exhibited a patchy temporal distribution (Figure 7). A strong cohesiveness with temperature and the degree of stratification and turbulence were observed at Stations 1 and 5. Stratification and the depth to which water was generally mixed downward appeared to affect phytoplankton diversity but it was also indirectly affected by zooplankton diversity via changes in phytoplankton size distribution (J. Ambler, unpublished data). Model simulations in multi-species simulations suggest that global patterns of phytoplankton diversity are determined by a few dominating species within each group (Adjou et al. 2012). We observed short successional cycles, which were possibly dependent on coastal upwelling events, and patches of certain taxa appeared to persist from roughly 2 to 6 weeks (Figure 7). We postulate that the persistence of these patches was related to the duration and strength of upwelling events, nutrient availability, and punctuated changes in temperature (Spatharis et al. 2011). Dinoflagellates and smaller flagellates appeared to be relatively more abundant in late summer when nutrients had become depleted. It appears that the distribution of phytoplankton classes occurred along a gradient of a " $\mathrm{r}$ vs. K” growth strategy, where diatoms (r-selected) exploited well-mixed, turbulent, nutrient-rich conditions, whereas dinoflagellates (K-selected) dominated in stable, stratified waters with low nutrient concentrations (Silva et al. 2009).

In summary, this study provides a 2-year time series that demonstrates how the MAB phytoplankton coastal assemblage responds to variability in wind forcing, which governs relatively short duration upwelling and downwelling events and temperature. The phytoplankton community was dominated by the diatoms Skeletonema costatum, Rhizosolenia spp., and Pseudo-nitzschia pungens throughout the year. Within the seasonal pattern, a series of short-term successions of various species, from r-strategists towards K-strategists, was associated with hydrodynamic changes promoted by upwelling/ relaxation events (Silva et al. 2009). Our study detected high amounts of inter-annual variability in phytoplankton biomass and seasonal changes in phytoplankton diversity in the southern MAB. The data collected during this project will help to interpret marine biological changes and begin to distinguish between anthropogenic, climatologically forced, and natural plankton variability.

\section{Acknowledgements}

This project was supported by NOAA and NASA and was managed by the Center for Innovative Technology. The paper was prepared under award \#NA03NOS4730220 from NOAA, U.S. Department of Commerce. The statements, findings, and conclusions are those of the authors and do not necessarily reflect the views of NOAA or the U.S. Department of Commerce. Thanks also to M.A. Linkswiler for graphics. In addition, we appreciate the hard work of the captain and crew of the R/V Philip N. Parker during cruises. We especially thank Robert N. Swift for his constructive comments, which always improve our manuscripts. We thank the reviewers for their excellent suggestions and detailed comments that greatly improved the manuscript.

\section{References}

Adjou, M., J. Bendtsen and K. Richardson. 2012. Modeling the influence from ocean transport, mixing and grazing on phytoplankton diversity. Ecol. Model. 225: 19-27.

Chavez, F.P, K.R. Buck and R.T. Barber. 1990. Phytoplankton taxa in relation to primary production in the equatorial Pacific. Deep-Sea Res. 37: 1733-1752.

Cox, J. and P.H. Wiebe. 1979. Origins of oceanic plankton in the middle Atlantic Bight. Estuar. Coast. Mar. Sci. 9: 509-527.

Fisher, T.R., E.R. Peele, J.W. Ammerman and L.W. Harding Jr. 1992. Nutrient limitation of phytoplankton in Chesapeake Bay. Mar. Ecol. Prog. Ser. 82: 51-63.

Fisher, T.R., A.B. Gustafson, K. Sellner, R. Lacoutre, L.W. Haas, R.L. Wetzel, R. Magnien, D. Everitt, B. Michaels and R. Karrh. 1999. Spatial and temporal variation of resource limitation in Chesapeake Bay. Mar. Biol. 133: 763-778.

Harding, L.W. Jr., B.W. Meeson and T.R. Fisher. 1986. Phytoplankton production in two east coast estuaries: photosynthesis-light functions and patterns of carbon assimilation in Chesapeake and Delaware Bays. Estuar. Coast. Shelf Sci. 23: 773-806.

Karl, D.M., R.R. Bidigare and R.M. Letelier. 2001. Long term changes in plankton community structure and productivity in 
the North Pacific Subtropical Gyre: the domain shift hypothesis. Deep-Sea Res. II 48: 1449-1470.

Keefe, C.W., K.L. Blodnikar, W.R. Boynton, C.A. Clark, J.M. Frank, N.L. Kaumeyer, M.M. Weir, K.V. Wood and C.F. Zimmermann. 2004. Nutrient analytical services laboratory standard operating procedures. Chesapeake Biological Laboratory Special Publication Series No. 55-80-04-CBL, University of Maryland Center for Environmental Science, Hornpoint, Maryland.

Kemp, P.F., B.F. Sherr, E.B. Sherr and J.J. Cole, eds. 1993. Handbook of methods in aquatic microbial ecology. Lewis Publishers, Boca Raton, FL. pp. 777.

Malone, T.C., H.W. Ducklow, E.R. Peele and S.E. Pike. 1991. Picoplankton carbon flux in Chesapeake Bay. Mar. Ecol. Prog. Ser. 78: 11-22.

Malone, T.C., S.E. Pike and D.J. Conley. 1993. Transient variations in phytoplankton productivity at the JGOFS Bermuda time series station. Deep-Sea Res. 1. Oceanogr. Res. Pap. 40: 903-924.

Marshall, H.G. 1976. Phytoplankton distribution along the eastern coast of the USA. Part I. Phytoplankton composition. Mar. Biol. 38: 81-89.

Marshall, H.G. 1984. Phytoplankton distribution along the eastern coast of the USA. Part V. Seasonal density and cell volume patterns for the northeastern continental shelf. J. Plankton Res. 6: 169-193.

Marshall, H.G. 1991. Preliminary results of phytoplankton composition, abundance and distribution in the lower Chesapeake Bay Monitoring Program. Special Report, Old Dominion University Research Foundation, Norfolk, VA, USA. pp. 61.

Marshall, H.G. and R. Lacouture. 1986. Seasonal patterns of growth and composition of phytoplankton in the lower Chesapeake Bay and vicinity. Estuar. Coast. Shelf Sci. 23: 115-130.

Marshall, H.G. and M.S. Cohn. 1987. Phytoplankton distribution along the eastern coast of the USA Part VI. Shelf waters between Cape Henry and Cape May. J. Plankton Res. 9: 139-149.

Moisan, J.R., T.A. Moisan and M.R. Abbott. 2002. Modelling the effect of temperature on the maximum growth rates of phytoplankton populations. Ecol. Mod. 153: 197-215.

Moisan T.A. and G.A. Fryxell. 1992. The distribution of Antarctic phytoplankton species in the Weddell Sea during austral winter. Bot. Mar. 36: 489-497.

Moisan T.A., K.L. Blattner and C.P. Makinen. 2010. Influences of temperature and nutrients on Synechococcus abundance and biomass in the southern Mid-Atlantic Bight. Cont. Shelf Res. 30: 1275-1282.

Moisan, J.R., T.A.H. Moisan and M.A. Linkswiler. 2011. An inverse modeling approach to estimating phytoplankton pigment concentrations from phytoplankton absorption spectra. J. Geophys. Res. 16: 0148-0227.

Moisan, T.A.H., S. Sathyendranath and H.A. Bouman. 2012. Ocean color remote sensing of phytoplankton functional types. In: (T.
Fatoyinbo, ed.) Remote sensing of biomass - principles and applications. Intech, Rijeka, Croatia pp. 101-122.

NOAA. 2007. NOAA Integrated Ocean Observing System (IOOS) Program Strategic Plan 2008-2014. US Department of Commerce, National Oceanic and Atmospheric Administration, National Ocean Service, NOAA IOOS Program, Silver Spring, MD, p. 4.

Pielou, E.C. 1966. Shannon's formula as a measure of specific diversity: its use and misuse. Am. Nat. 100: 463-465.

Roman, M., X. Zhang, C. McGilliard and W. Boicourt. 2005. Seasonal and annual variability in the spatial patterns of plankton biomass in Chesapeake Bay. Limnol. Oceanogr. 50: 480-492.

Shannon, C.E. and W. Weaver, 1949. The mathematical theory of communication. University of Illinois Press, Urbana, IL, USA. pp. 117.

Sherr, E.B., D.A. Caron and B.F. Sherr. 1993. Staining of heterotrophic protists for visualization via epifluorescence microscopy, In: (P. Kemp, ed.) Handbook of methods in aquatic microbial ecology. CRC Press, Boca Raton, FL, pp. 213-227.

Silva A., S. Palma, P.B. Oliveira and M.T. Moita. 2009. Composition and interannual variability of phytoplankton in a coastal upwelling region (Lisbon Bay, Portugal). J. Sea Res. 62: 238-249.

Smayda, T.J. 1997. Harmful algal blooms: their ecophysiology and general relevance to phytoplankton blooms in the sea. Limnol. Oceanogr. 42: 1137-1153.

Smayda, T.J. 1998. Patterns of variability characterizing marine phytoplankton with examples from Naragansett Bay. ICES J. Mar. Sci. 55: 562-573.

Smayda, T.J., D.G. Börkman, G. Beaugrand and A. Belgrano. 2004. Responses of marine phytoplankton populations to fluctuations in marine climate. In: (N.C. Stenseth, G. Ottersen, J.W. Hurrell and A. Belgrano, eds). Marine ecosystems and climate variation: the north Atlantic: a comparative perspective. Oxford University Press, New York. pp. 49-58.

Spatharis S., D.L. Roelke, G. Panayiotis, G. Dimitrakopoulos and G.D. Kokkoris. 2011. Analyzing the (mis)behavior of Shannon index in eutrophication studies using field and simulated phytoplankton assemblages. Ecol. Indic. 11: 697-703.

Watling, L., D. Bottom, A. Pembroke and D. Maurer. 1979. Seasonal variations in Delaware Bay phytoplankton community structure. Mar. Biol. 52: 207-215.

Welschmeyer, N.A. 1994. Fluorometric analysis of chlorophyll $a$ in the presence of chlorophyll $\mathrm{b}$ and pheopigments. Limnol. Oceanogr. 39: 1985-1992.

Wong, K.-C. 2002. On the wind-induced exchange between Indian River Bay, Delaware and the adjacent continental shelf. Cont. Shelf Res. 22: 1651-1668.

Received 6 February, 2012; accepted 22 June, 2012; online first 10 September, 2012 
Copyright of Botanica Marina is the property of De Gruyter and its content may not be copied or emailed to multiple sites or posted to a listserv without the copyright holder's express written permission. However, users may print, download, or email articles for individual use. 